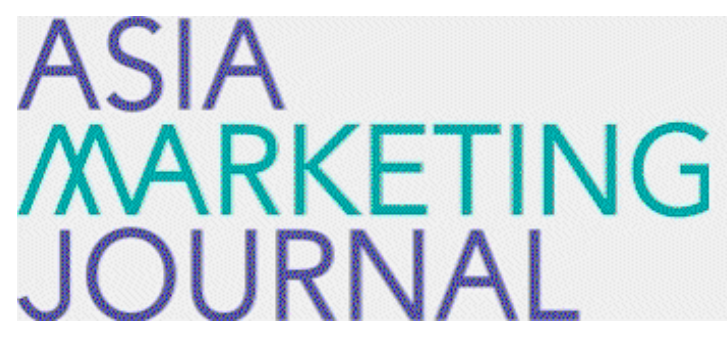

ASIA MARKETING JOURNAL

Volume 7 | Issue 2

Article 3

7-27-2005

\title{
통신서비스 이룡형태 분석을 통한 휴대폰 교체기간 예측
}

Hyun Jung Park

Sang Hoon Kim

Follow this and additional works at: https://amj.kma.re.kr/journal

Part of the Marketing Commons

\section{Recommended Citation}

Park, Hyun Jung and Kim, Sang Hoon (2005) "톻신서비스 이룡형태 분석을 톻한 휴대폰 교체기간 예측," Asia Marketing Journal: Vol. 7 : Iss. 2 , Article 3.

Available at: https://doi.org/10.53728/2765-6500.1142

This Article is brought to you for free and open access by Asia Marketing Journal. It has been accepted for inclusion in Asia Marketing Journal by an authorized editor of Asia Marketing Journal. 


\title{
통신서비스 이용행태 분석을 통한 휴대폰 교체기간 예측*
}

\section{Telecommunication Service Usage as Predictor of the Timing of Handset Buyers' Replacement Purchases*}

\author{
박 현 정(Park, Hyun Jung) ${ }^{* *}$ \\ 김 상 훈(Kim, Sang-Hoon)**
}

기술의 발달에 힘입어 업그레이드된 휴대폰이 매우 활발하게 출시되고 있고, 번호이동성 제도가 도 입되면서 휴대폰 교체수요가 급증하고 있다. 이동통신 서비스와 휴대폰 단말기의 상호 보완관계는 매 우 크다고 할 수 있는데, 고객들이 고사양의 최신 휴대폰으로 업그레이드 할 경우 다양한 서비스의 이용이 가능하여 인당서비스수익(ARPU)의 증대도 기대할 수 있다. 이와 같이 이동통신 서비스 제 공자의 입장에서 자신이 보유하고 있는 서비스 이용행태 자료들을 활용하여 고객들의 신규 단말기 구매시점을 예측할 수 있다면 이는 매우 유용한 전랴적 정보가 될 것이다. 즉 교체구매에 대한 소비 자의 행동을 이해하여 조기수용자 층을 공략할 수도 있고 단말기 교체시기를 관리하여 서비스 관계 를 강화할 수 있다. 본 연구에서는 이동통신 서비스 제공자가 보유하고 있는 고객의 서비스 이용행태 자료만을 활용하여, 휴대폰 사용자가 신제품으로 교체구매를 하는데 소요되는 기간에 영향을 주는 변 수들 즉 혁신적 서비스 사용, 부가서비스 사용경험, 통화서비스 사용정도, 로열티 프로그램 참여 등의 효과를 분석하고 휴대폰 교체시기를 예측하는 모형을 개발하여 실증적으로 검증하였다. 변수들의 효 과에 대한 가설 검증 결과는 다양한 실무적 시사점을 제공하고 있으며, 모형의 예측타당성도 입증되 었다.

핵심개념: 교체구매, 텔레커뮤니케이션, 타이밍

\section{I. 서 론}

이동전화 단말기 시장이 포화 상태에 있고 차
세대 이동전화 서비스가 잇따라 등장하면서 단 말기 교체시장이 급성장하고 있다. 휴대폰 제조 기업들은 교체구매 시장을 장악하기 위해 디자 인 향상, 다양한 부가기능 접목, 컨버전스 제품

\footnotetext{
* 자료를 제공해주신 기업 관계자분들께 감사드립니다.

** 서울대학교 대학원(great3@snu.ac.kr)

*** 서울대학교 경영대학 조교수(profkim@snu.ac.kr)
} 
출시 등과 함께 신제품 개발에 박차를 가하고 있다. 또한 번호 이동성 제도가 도입됨에 따라 이동통신 서비스의 교체 및 전환 경쟁이 치열 해지고 있으며, 이는 단말기의 교체로 이어져 휴대폰의 교체수요가 급증하고 있다. 이러한 상 황에서 이동통신 서비스 제공자들은 신규 고객 을 유치하고 기존 고객의 전환을 막기 위하여 교체구매에 대한 소비자의 특성과 구매 행동을 이해해야 한다. 소비자들은 서비스 제공자를 바 꾸기 위해 단말기를 교체하기도 하고, 신종 단 말기를 이용하기 위해 서비스 제공자를 바꾸기 도 한다. 그러므로 고객 이탈을 막기 위한 유용 한 마케팅 전략 중의 하나는 자사 고객의 단말 기 교체를 적절히 관리하여 서비스 관계를 고 착(lock-in)시키는 것이다. 따라서 소비자들이 교체 구매하는 타이밍에 대한 연구는 마케터가 신제품의 조기수용자 충을 파악하고 공랴하거 나 제품 교체가 예상되는 고객을 적시에 관리 하는데 중요한 시사점을 줄 수 있다.

그동안 교체구매(replacement purchase) 행동 에 대한 연구들은 다수 있었지만 자동차(Bayus 1991), 냉장고, 세탁기, TV, 커피 메이커(Bayus and Mehta 1995)와 같은 전통적인 내구재에 한정되며 기간에 대한 연구도 매우 임의적인 수준에 그쳤는데, 최근에서야 $\mathrm{PDA}$ 와 같은 하 이테크 제품의 교체구매 기간에 대한 연구가 이루어졌다(e.g: Kim and Srinivasan 2003). 본 논문에서는 신제품 출시가 매우 활발하고 제품 교체주기가 점차 짧아지고 있는 대표적인 내구 재인 휴대폰의 교체를 중심으로 하여 소비자의 제품 교체기간의 영향요인에 대해 연구하고자 한다.

본 연구는 이동통신 서비스 제공자가 보유하고
있는 소비자의 서비스이용행태 자료(behavioral data) 만을 활용하여 소비자의 휴대폰 교체에 소요되는 기간에 영향을 미치는 요인과 그 영 향력의 크기를 분석하고, 향후 제품 교체시기 를 예측하는 모형을 수립하는 것을 목적으로 한다. 휴대폰 사용자의 교체구매 기간에 영향 을 미치는 요인으로는 기업으로부터 협조 받은 내부 자료의 특성을 토대로 서비스 이용행태 자료를 위주로 하여, 혁신적 서비스 사용, 부가 서비스 사용경험, 통화서비스 사용정도, 로열티 프로그램 참여, 인구통계 변수를 포함시켜 분 석하였다.

\section{II. 이론적 배경}

\section{1 제품 교체구매에 대한 연구}

일반적으로 제품 교체구매는 제품 고장 등으 로 인하여 불가피하게 새로운 제품을 구매하는 정상적인 교체(normal replacements)와 소비자 의 선택적인 의사결정에 따른 재량 교체(discretionary replacements)의 두 가지 형태로 분류 할 수 있다(Bayus 1991). 소비자들은 스타일이 나 패션 선호(DeBell and Dardis 1979: Hoffer and Reilly 1984), 제품 속성과 기술 발전(Katona 1960; Muller 1958), 가격과 프로모션(Bayus 1988: Katona and Muller 1954; Quelch, Neslin, and Olson 1987) 등과 같은 다양한 이유로 아 직 사용 가능한 정상적인 제품들을 신제품으로 교체하는 의사결정을 내리는 것이다. 하이테크 제품의 경우 제품교체는 정상적인 교체보다는 
대부분 이와 같은 재량 교체의 형태를 띄는데 (Bayus 1992), 높은 전환 비용으로 인하여 같 은 제품 타입이나 브랜드로 교체구매가 이루어 지는 경우가 많다.

소비자의 교체구매 시기에 대한 첫 실증적 연 구를 시도한 Bayus(1988)는 에너지 가전제품의 교체시기에 가구의 인구통계 변수와 제품의 속성이 유의한 영향을 미친다는 것을 보였다. 1991년에는 자동차 교체구매 시기가 빠르고 늦 은 소비자로 나누어 소비자의 인구통계적인 특 성, 소비자의 태도와 인지, 탐색 활동에서의 차 이점을 연구하였는데, 제품 교체 기간이 짧은 소비자는 스타일이나 이미지와 같은 제품 속성 에 관심이 있는 반면, 교체 기간이 긴 소비자는 가격과 같은 또다른 제품 속성에 관심이 있는 것으로 나타났다. Bayus and Mehta(1995)는 연구의 범위를 냉장고, TV, 커피 메이커 등 다 른 내구재들로 확장함으로써 교체구매 하는데 걸리는 기간에 따라 소비자를 나누는 시장세분 화 기법을 보다 일반화하였다.

기타 기존의 실증연구를 종합해 보면, 소비자 의 제품 교체기간에는 소비자의 인구통계 변수 (Bayus 1991), 소비자 혁신성(Cestre and Darmon 1998), 전환비용(Eliashberg and Robertson 1988;

Heide and Weiss 1995: Kim and Srinivasan 2003), 소비자 지식. 마케팅 변수(Raymond et al. 1993) 등 다양한 요인이 영향을 미치는 것 으로 알 수 있다.

\section{2 제품 교체기간의 영향변수}

본 연구에서는 서비스 제공자가 보유하고 있 는 소비자의 서비스이용행태 자료(behavioral data)만을 활용하여 교체구매 시기를 예측하는 것이 목적이므로, 설문자료나 제품 관련 자료에 서 얻을 수 있는 변수는 제외하고 서비스 이용 행태 위주의 변수들을 고려하였다. 혁신적 서비 스 사용, 부가서비스 사용경험, 통화서비스 사 용정도, 로열티 프로그램 참여, 인구통계 변수 라는 5 가지 변수를 제품 교체 기간에 영향을 주는 주요 요인들로 선정하였는데, 인구통계 변 수를 제외한 각 요인의 선정과 관련된 이론적 배경을 정리하면 다음과 같다.

\subsection{1 소비자 혁신성}

소비자 혁신성(consumer innovativeness)이란 '사회시스템 내에서 개인이 다른 구성원보다 혁 신을 상대적으로 빨리 수용하는 성향이며, 혁신 자들(innovators)은 새로운 경험과 새로운 자극 을 선호하는 개인들이라 할 수 있는데(Leavitt and Walton 1975) Cestre and Darmon(1998) 은 소비자 혁신성의 정도가 신제품을 구매하는 데 걸리는 시간에 영향을 미치는 주요 요인이 라고 설명하고 있다.

Thorelli and Eagledow(1980)는 정보를 적극 적으로 추구해 나가는 정보 추구자(information seeker)들이 존재한다고 보았는데, 혁신자적인 소비자들은 이러한 정보추구자일 가능성이 높 다. 또한 이들은 상표 충성도가 낮아 자주 상표 를 전환하는 다양성 추구(variety seeking) 소 비자일 가능성이 높으며(Hoyer and Ridgway 1984), 특정 제품에 대해서 제품 열광자(product enthusiast)일 가능성이 있다. 신제품 구입 시 위험을 감수하려는 의지인 모험심도 혁신자와 비혁신자의 차이를 설명할 수 있는 요인이다 
(Robertson and Kennedy 1968), 한편, 개인 이 가장 선호하는 자극수준인 최적 자극수준 (optimum stimulation level; OSL)은 감각추구 측정도구를 사용하여 측정할 수 있는데 $(\mathrm{Me}-$ hrabian and Russell 1974: Zuckerman 1979), Raju(1980)의 연구에 의하면 이 점수가 높은 사람들이 혁신적인 것으로 나타났다. Goldsmith and Hofacker(1991)는 개인의 혁신성을 측정하는 방법을 개발하였고 Baumgartner and Steenkamp (1996)는 혁신적이고 탐험적인 소비 행태를 측 정할 수 있는 지표를 개발한 바 있다.

혁신 제품이나 서비스를 수용하는데 걸리는 시간에 따라서 소비자를 다섯 가지의 수용자 범주(adopter category)로 범주화시킬 수가 있 는데(Rogers 1976), Moore(1991)의 이른바 "캐 즘 모형”도 이러한 수용자 범주 이론에 근거하 고 있다. 소비자는 혁신 제품을 수용함에 있어 서 기술 애호가인 혁신 수용자(innovators), 선 각자인 조기 수용자(early adopters), 실용주의자 의 성격을 가진 전기다수 수용자(early majority), 보수주의자인 후기다수 수용자(late majority). 회의론자인 지각 수용자(laggards)로 나뉘며, 그 중 혁신 수용자는 새로운 기능의 신제품을 남들보다 일찍 구매하므로 교체구매 주기도 짧 을 것으로 예상된다.

\section{2 .2 소비자 지식}

소비자 지식이란 '소비자들이 제품과 관련하 여 가지고 있는 정보나 경험, 또는 친숙성의 정 도'를 뜻한다(Alba and Hutchinson, 1987). Moreau, Lehmann and Markman(2001)은 제 품의 혁신성 및 제품 카테고리에 관한 소비자
지식을 고려하여 신제품에 관한 이해, 수용, 선 호도 등을 조사한 결과, 신제품에 대한 이해도, 인식된 효용의 정도, 선호도 등이 지식수준에 따른 집단 간에 차이가 있다는 결론을 도출하 였다. 한편, 소비자들의 혁신제품에 대한 저항 은 혁신에 대한 정보가 확실치 않고 그것에 대 한 신념이 강하지 않을 때 유발된다는 연구결 과도 있다(유필화, 이승희 1994). 따라서 제품 지식수준이 높아질수록 교체구매에 대한 의도 가 증가할 것으로 추론할 수 있다.

학자들은 소비자 지식을 주관적 지식과 객관 적 지식으로 구분하여 연구를 진행하고 있으며 경험에 의한 지식이라는 개념도 새로이 추가되 고 있다(Park et al. 1994). 주관적 지식은 본인 이 가진 지식수준에 관한 자신감이라고 할 수 있으며(Alba and Hutchinson 1987; Park et al. 1994) 객관적 지식은 소비자의 기억에 저 장되어 있는 제품에 관한 정보나 지식으로서 (Brucks 1985) 주관적 지식에 영향을 미친다 (최낙한, 황윤용 1998). 경험에 의한 지식은 제 품에 대한 탐색 경험, 사용의 경험, 실제 소유의 경험으로 분류할 수 있다. Mason and Bequette (1998)는 소비자의 제품 사용경험 수준이 높을 수록 제품 속성의 성과를 더욱 정확하고 효과 적으로 기억 내에 저장하거나 인출할 수 있다 고 하였다.

Engel, Blackwell and Miniard(1995)는 소비 자 지식의 내용을 제품지식(product knowledge). 구매지식(purchase knowledge), 그리고 사용지 식(usage knowledge)의 유형으로 정리하였는 데, 이것은 소비자 행동의 주요변수인 제품, 구 매상황, 사용상황을 고려한 종합적인 소비자 지 식의 분류체계로 평가된다. 또한 소비자 연구자 
들은 소비자 지식을 측정하기 위해서 다양한 접근방법을 활용해 왔는데. 그 구체적인 방법은 객관적 지식척도, 주관적 지식척도, 경험기반형 지식척도의 세 가지 유형으로 분류할 수 있다. 객관적 지식척도(objective knowledge measure) 는 지식의 객관적인 테스트를 이용해서 소비자 들이 기억하고 있는 내용을 직접적으로 평가하 는 방법이며(Rao and Monroe 1988), 주관적 지식척도(subjective knowledge measure)는 지 식의 자기평가측도를 이용해서 소비자의 지식 수준에 대한 소비자 스스로의 지각을 파악하는 방법이다(Rethans et al. 1986). 경험기반형 지 식척도(experience-based knowledge measure) 는 소비자의 구매경험 혹은 사용경험의 양을 조사해서 이것을 소비자 지식의 지표로 파악하 는 방법인데(Bettman and Park 1980) 본 논문 에서는 소비자의 경험지식에 초점을 맞추어 경 험기반형 지식척도를 사용한다.

\subsection{3 제품 사용정도}

Twedt(1964)는 구매의 빈도(frequency)를 기 준으로 소비자 시장을 비사용자(non-user), 소 량 사용자(light user or occasional user), 혜비 유저(heavy user)라는 세 개의 세분집단으로 나눌 것을 처음으로 제시하였다.

Goldsmith and Flynn(1994)과 Goldsmith and Litvin(1999)의 연구는 와인과 관광산업에 서 헤비 유저의 특성에 대해 규명하였는데. 헤 비 유저들이 비사용자나 소량 사용자에 비해 몰입을 더 많이 하고 혁신적이며 지식도 더 많 은 것으로 나타났다. 또한 오피니언 리더일 가 능성이 높고 모든 형태의 미디어(잡지, 신문,
$\mathrm{TV}$, 책 그리고 박람회)에서 정보를 습득하는 것으로 나타났다. 연구들에 따르면 혁신자들은 비혁신자보다 제픔 카테고리에서 더 많이 돈을 쓰고 더 많이 구입하는데(Goldsmith and Flynn 1994; Goldsmith and d'Hauteville 1998), Goldsmith (2001)는 혁신자들은 대부분 헤비 유저이 기 때문이고 혁신자들이 사는 신제품들은 기존 제품들보다 가격이 더 높기 때문일 것이라고 설명하고 있다.

Morgan(1979)은 신제품의 조기 채택자가 그 제품의 헤비 유저이기도 한지, 같은 제품군의 추가 제품을 살 경향이 높은지에 대하여 연구 하였다. 식품과 은행 서비스에 대하여 검증한 결과 이 같은 상관관계가 나타났기 때문에 헤 비 유저 세분 시장의 특성을 관찰하고 이들을 대상으로 하는 마케팅 프로그램의 필요성이 제 기되었다. 그러나 TV 프로그램의 선택에 있어 서는 헤비 유저의 인구통계적인 톡성들이 구매 행위를 잘 설명하지 못한다는 상반되는 연구결 과도 있다(Assael and Poltrack 1994).

헤비 유저일수록 소비자 지식이 많고 혁신적 이며 신제품을 빨리 채택할 가능성이 높기 때 문에 이들의 휴대폰 교체구매 시기가 짧을 것 이라고 예측할 수 있으나. 제품 카테고리마다 영향력의 크기에 있어서 차이가 나기 때문에 검증이 필요하다.

\section{2 .4 고객 참여}

서비스가 복잡하고 환경변화가 유동적이며 미 래의 수요 및 공급 상황이 불확실할수록 서비 스 제공자와 고객의 관계는 더욱 중요해진다 (Zeithaml et al. 1985). 본 연구에서는 서비스 
제공자와 고객 간의 관계적 특성을 소비자의 로열티 프로그램 참여를 중심으로 살펴보았는 데, 고객 참여란 '서비스의 생산과 공급에 있어 서 소비자의 참여가 필수적인 경우에 소비자가 정신적 혹은 물리적으로 기울이는 노력 및 관 심의 정도'라고 정의할 수 있다(Solomon et al. 1985).

서비스 접점에서의 소비자 행동이 성격 특성. 자아 이미지, 필요, 사회적 역할, 지각 등 소비 자의 특성에 따라 상이하다는 Langeard et al. (1981)의 연구와 함께, 서비스 생산에 대한 참 여정도는 개인의 경제적, 사회적, 문화적 요인 에 따라 상이하다는 Andreasen(1983)의 연구를 참고하면, 로열티 프로그램에 참여하는 고객이 참여하지 않는 고객과는 다른 특성을 가지고 있다고 볼 수 있다. 이들은 적극적인 성격과 더 불어 서비스 자체에 대한 니즈와 관심이 있기 때문에 신규 부가서비스 등에 대한 관여도가 높을 것으로 보여, 신제품을 시용(trial)하거나 교체구매에 대한 의도가 클 것이라고 추론할 수 있다.

Kelly et al.(1990)은 서비스의 생산 및 전달과 정에 있어서 서비스 접점에서의 고객 참여에 대 한 고객 서비스의 역할을 규명하였고 Goodwin and Radford(1993)는 서비스 제공자의 서비스 접점에서의 투입요소에 대한 통제 능력과 서 비스 전달 시스템 상에서의 고객참여 모델을 제시하고 있다. 결국 소비자의 서비스 접점 만 족이나 구매 후 결과의 만족 정도를 높이기 위 해 고객의 참여 정도를 극대화시키는 전략이 매우 효과적인 것으로 나타나고 있다(Cronin and Taylor 1992: Berry and Parasuraman 1993).
몇몇 연구들은 서비스 제공자와 고객 간의 관 계의 질(relationship quality)이라는 개념을 제 시하였는데(Cosby 1989: Cosby et al.1990), 관 계의 질은 '서비스 제공자를 대표하는 접점요원 에 대한 장기적인 관점에서의 소비자의 평가'로 서(Swan et al. 1985) 서비스를 제공하는 접점 요원에 대한 소비자의 신뢰(Cosby and Stephens 1987)가 재구매 의도에 영향을 미친다고 한다. 한편, 서비스 이용에 대한 만족 수준이 높은 소 비자는 재구매 의사결정시 서비스 제공자와의 관계에 그리 큰 영향을 받지 않을 것이나. 서비 스 만족이 높지 않은 경우 소비자들의 재구매 의도는 서비스 제공자가 소비자와 얼마나 좋은 관계를 형성하려고 했는가에 의해 상대적으로 크게 영향을 받는다는 연구도 있다(박정은 외 1998). 멤버십 서비스와 같은 로열티 프로그램 은 서비스 제공자와 고객의 관계적 특성에 긍 정적인 효과를 가지며, 소비자의 기업에 대한 평가 기회를 늘리고 제품의 교체의도에도 긍정 적인 영향을 미칠 수 있을 것이다.

\section{III. 실증연구}

\section{1 연구 모형 및 가설}

본 논문에서는 휴대폰 사용자가 신제품으로 고체 구매하기까지 소요되는 시간에 영향을 미 칠 수 있는 요인을 앞 절에서 살펴본 4 가지 개 념과 인구통계 변수를 포함한 5 가지로 구분하 였다. 소비자의 통신서비스 이용행태 변수들 중 에서 앞에서 서술한 4 가지 요인과 직접적으로 
〈그림 3-1〉 연구의 개념적 모형

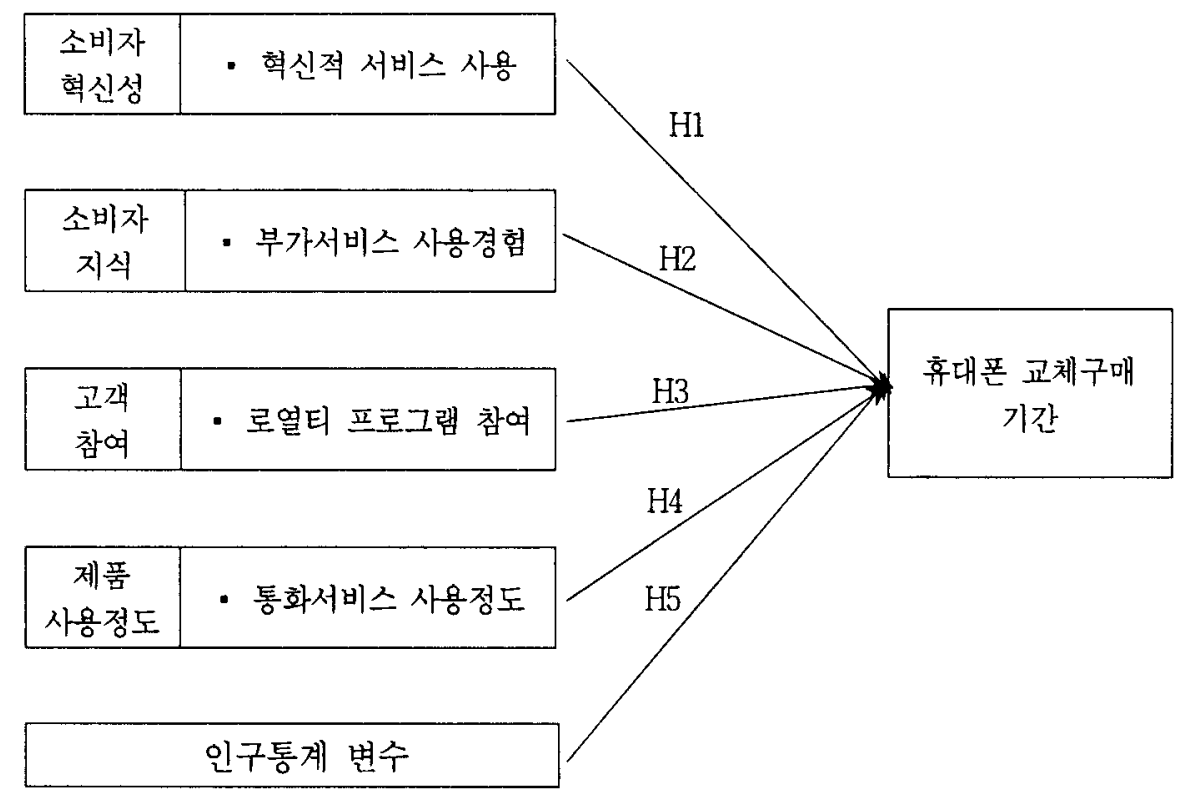

관련된 변수들을 가지고 실증연구 모형을 구성 하면 다음 〈그림 3-1〉과 같다.

\subsection{1 혁신적 서비스 사용}

이동통신 서비스 사업자의 고객 데이터베이스 상에 소비자 혁신성에 대한 자료가 존재하지 않으므로 소비자 혁신성과 가장 관련이 높을 것으로 보이는 대용(proxy) 행태 변수로서 무 선인터넷 서비스나 혁신적인 부가 서비스 사용 여부가 적합한 것으로 판단하였다.

2003년 6월 현재 이동전화 소유자의 $36 \%$ 가 최근 6 개월 이내에 무선인터넷을 이용해 본 경 험이 있으나 이들의 $10 \%$ 만이 매일 이용하는 것으로 나타났고(한국인터넷정보센터 2003), RI 코리아와 코리안클릭의 공동조사에 의하면 2003 년 현재 전체인구의 $13 \%$ 만이 월 1 회 이상 이
용하고 있는 것으로 나타났다(코리안클릭 2003). 따라서 무선인터넷을 아직 이용하고 있지 않는 사람들의 $90 \%$ 이상이 무선인터넷에 관해 이미 알고 있다는 점을 고려할 때, 이러한 이용현황 에 대한 조사는 무선인터넷의 확산이 아직 낮 은 수준에 머물러 있음을 보여주는 것으로 이 해할 수 있다.

혁신자들은 정보를 적극적으로 추구하고(Thorelli and Eagledow 1980) 신제품을 구입 시 위험 을 감수하려는 모험심이 크므로(Robertson and Kennedy 1968), 확산과정에서 볼 때 아직 도입 단계라 할 수 있는 이와 같은 서비스를 사용하 는 소비자는 혁신성이 높은 소비자라고 할 수 있으며, 이들은 무선인터넷 서비스나 혁신적인 부가 서비스를 사용하지 않는 소비자들보다 휴 대폰의 교체 구매 기간이 짧을 것이라고 예상 하였다. 
H1(a) 무선인터넷 서비스를 사용하는 소비 자들이 사용하지 않는 소비자들보 다 휴대폰 교체구매 기간이 짧을 것 이다.

(b) 혁신적인 부가서비스를 사용하는 소비 자들이 사용하지 않는 소비자들보다 휴대폰 교체구매 기간이 짧을 것이다.

\section{1 .2 부가서비스 사용경험}

소비자 지식은 제품지식, 구매지식, 사용지식 의 세 가지 유형으로 분류할 수 있는데(Engel et al. 1995) 본 연구에서는 사용지식(usage knowledge)을 중심으로 분석하였다. 앞에서 언 급한 바와 같이 본 논문에서는 소비자의 구매 경험 혹은 사용경험의 양을 소비자 지식의 지 표로 파악하는 방법으로서 경험기반형 지식척 도(experience-based knowledge measure) 를 토 대로 분석하였는데(Bettman and Park 1980) 이는 소비자의 제품사용 경험이 많으면 많을수 록 이것이 곧 소비자 지식으로 자연히 전환된 다는 기본 전제에 입각하고 있다. 따라서 휴대 폰 서비스에 대한 사용지식은 서비스 사용경험 이 많을수록 증가한다고 보고, 이는 이용하는 부가서비스의 종류 수, 부가서비스 요금, 무선 인터넷 서비스 이용시간 등과 관련되어 있을 것으로 보았다.

소비자 사용경험이 충분할수록 적극적인 소 비자 의사결정이 가능할 것이고. 제품 지식수 준이 높지 않은 소비자에 비하여 신제품에 대 한 이해도, 인식된 호용의 정도, 제품 속성 기 억 및 인출 능력이 높으므로 교체구매 결정을 앞당길 가능성이 많다. 족 다양한 종류의 부가
서비스를 많이 이용하거나 무선 서비스 이용시 간과 요금이 많을수록 서비스 지식이 많을 것 이고 이들은 교체구매 기간이 상대적으로 짧을 것이다.

H2(a) 사용하는 부가서비스 종류가 많은 소 비자일수록 휴대폰 교체구매 기간이 짧을 것이다.

(b) 부가서비스 이용요금이 높은 소비자일 수록 휴대폰 교체구매 기간이 짧을 것 이다.

(c) 무선인터넷 서비스 이용시간이 긴 소 비자일수록 휴대폰 교체 구매 기간이 짧을 것이다.

\section{1 .3 통화서비스 사용정도}

부가서비스 사용경험과 별도로 통화요금, 통 화시간, 요금제 수준 등 통화서비스 사용 정도 에 대한 가설을 수립하였는데, 이는 다양한 부 가서비스나 무선인터넷 서비스의 경우 사용자 의 서비스 사용지식과 관련되어 있는 반면, 통 화량의 경우는 지식 측면보다는 단순히 이용 강도를 나타내는 것으로 보는 것이 더욱 타당 할 것이기 때문이다. 월평균 통화요금과 월평 균 통화시간은 서로 연관성이 매우 높지만 기 본 요금제의 수준에 따라 10 초당 통화요금이 달라지기 때문에, 헤비 유저를 가려내는 데는 월평균 통화시간이 더욱 정확할 것이다. 하지 만 임의로 변수를 배제하기보다 데이터베이스 상의 활용 가능한 변수는 모두 포함시켜보고 변수들의 영향력을 판단하고자 하였다. 다중공 선성으로 인한 모형의 유의성 저하를 방지하 
기 위해 다음 장에서는 개별 변수만을 고려한 모형을 우선 검증하여 각각의 변수에 대한 유 의성을 살펴볼 것이다. 그리고 일반적으로 요 금제 수준이 높을수록 10 초당 부과되는 통화 요금이 적어지므로 높은 수준의 요금제는 해 비 유저가 사용할 가능성이 높을 것이라고 가 정하였다.

해비 유저일수록 소비자 지식이 많고 혁신 적일 가능성이 높으며(Goldsmith and Flynn 1994; Goldsmith and Litvin 1999) 신제품 채 택과도 관련성이 있기 때문에(Morgan 1979) 휴대폰의 교체구매 시기가 짧을 것이라고 예 측할 수 있으므로 다음과 같이 가설을 수립하 였다.

H3(a) 월평균 통화시간이 긴 소비자일수록 휴대폰 교체구매 기간이 짧을 것이다.

(b) 월평균 통화요금이 높은 소비자일수록 휴대폰 교체구매 기간이 짧을 것이다.

(c) 요금제 수준이 높은 소비자일수록 휴 대폰 교체구매 기간이 짧을 것이다.

\subsection{4 로열티 프로그램 참여}

이동통신 서비스의 로열티 프로그램에 참여하 는 고객은 참여하지 않는 고객과 여러 가지 측 면에서 다른 톡성을 보일 것이다. 소비자의 특 성, 예를 들어 성격특성, 자아 이미지, 필요, 사 회적 역할, 지각 등에 따라(Langeard et al. 1981), 개인의 경제, 사회, 문화적 요인에 따라 서비스 생산에 참여하는 정도가 상이하다는 연 구결과(Andreasen 1983)들이 이러한 주장을 지 지한다. 로열티 프로그램에 참여하는 고객은 적
극적인 성격과 더불어 서비스 자체에 대한 니 즈와 관심이 있기 때문에 신규 부가서비스 등 에 대한 관여도가 높을 것으로 보여, 참여하지 않는 소비자에 비하여 신제품을 시용(trial)하거 나 교체구매 할 의도가 클 것이라고 추론할 수 있다.

로열티 프로그램은 서비스 제공자가 소비자 와 지속적인 관계 형성을 해나가려는 노력의 일환이며, 소비자가 참여하여 서비스를 이용한 다면 서비스 제공자에 대한 평가의 기회가 늘 어나게 되고 제품의 교체의도에도 영항을 미칠 수 있을 것으로 보고 다음과 같이 가설을 수립 하였다.

$\mathrm{H4}$ 멤버십 서비스에 가입한 소비자들이 가입 하지 않은 소비자들보다 휴대폰 교체구매 기간이 짧을 것이다.

\subsection{5 인구통계 변수}

휴대폰과 관련하여 수행된 기존의 연구는 주 로 집단 간 소비자 행동을 설명하는 것으로서 인구통계 변수나 생활양식에 따른 휴대폰 서비 스의 이용 수준이나 행태에 관한 연구가 많은 부분을 차지하고 있다. 구쳬적으로 살펴보면, 휴대폰에 대한 사용비용은 연령과 성뼐에 따라 차이를 보이는 것으로 나타났는데, 여성보다는 남성이, 중장년층보다 젊은 층일수록 더 많은 비용을 지불하는 것으로 나타났다(한국소비자 보호원 2001). 구매행위가 소비자 태도에 의해 영향을 받는 '행위에 우선하는 태도(attitudebefore-behavior)' 이론(Engel et al. 1995)에 따 르면 휴대폰 사용에 대한 소비자의 태도가 호 
의적일수록 휴대폰 사용비용이 증가한다고 볼 수 있다. 따라서 소비자의 나이와 성별과 같은 인구통계 변수가 교체구매 기간과도 관련이 있 을 것이라고 예상하였다. Im et al.(2003)의 연 구에서는 가전제품 카테고리에서 소비자의 나 이가 신제품 채택의 예촉에 도움이 되는 것으 로 나타났으나 휴대폰이라는 제품 카테고리에 서도 영향력이 있을지의 여부는 검증해 보아야 할 것이다.

$\mathrm{H} 5$ (a) 나이가 적을수록 후대폰 교체구매 기 간이 짧을 것이다.

(b) 남성이 여성보다 휴대폰 교체구매 기 간이 짧을 것이다.

\section{2 자료 및 변수의 조작적 정의}

연구모형과 가설을 검증하기 위하여 국내의 한 이동통신 서비스 제공업체로부터 고객 데이 터베이스의 일부 자료를 협조 받았다. 2003년 한 해 동안에 단말기를 교체한 고객을 대상으 로 하여 수집된 자료 중에서, 사용자 정보의 보 안 상 기업에서 임의로 추출하고 프로파일을 배제한 150 명의 자료를 바탕으로 분석을 실시 하였다.

\subsection{1 종속변수}

본 연구의 종속변수는 휴대폰 교체구매에 소 요된 기간(duration)으로서 최근 휴대폰을 교체 구매한 날짜와 그 이전에 구매하였던 날짜 사 이의 기간으로 정의된다. 본 연구에서는 자료의 한계로 인하여 2003년 한 해 동안에 일어난 교
체구매만을 분석하였는데, 그 기간 동안 기기를 두 번 구매한 고객을 교체 구매한 고객으로 분 류하였고, 따라서 교체 구매 기간이 1년 이상인 소비자는 분석에 포함시킬 수 없었다. 그 기간 중 한 번만 구매한 고객의 경우 마지막 일자에 서 절단(censored)된 것으로 간주하여 휴대폰 구매일로부터 마지막 일자까지의 기간을 교체 구매 기간으로 계산하였다. 기간 단위는 일(日) 단위로 하였다.

\section{2 .2 독립변수}

첫째, 혁신적 서비스 사용의 측정항목은 무 선인터넷 서비스 이용여부와 혁신적 부가 서 비스 이용여부의 두 가지 항목으로 하였다. 무 선인터넷 서비스를 이용한 사람은 1 , 이용하지 않은 사람은 0점을 주었고, 소비자와 전문가의 의견을 토대로, 도입된 지 오래되지 않은 신규 서비스이거나 내용이나 사용이 복잡하여 아직 소비자들 사이에서 확산된 정도가 낮은 서비 스일수록 혁신적인 서비스로 간주하여 점수화 하였다. 구체적으로 연결음 서비스와 같은 경 우 가장 낮은 1 점. 유무선으로 연동되는 문자 메시지는 2점, 스팸 문자 차단 서비스는 3점, 최근 도입된 신규 서비스이며 소비자들이 아 직 잘 이용하고 있지 않은 상대방 위치추적 서비스와 같은 경우에는 가장 높은 5점을 부 여하였다.

둘째, 부가서비스 사용경헙의 측정항목으로서 현재 사용하고 있는 부가서비스의 종류 수와 부가서비스 이용요금 외에 무선 인터넷서비스 의 이용요금을 포함시켰다.

셋째, 통화서비스 사용정도는 월평균 통화시 
〈표 3-1〉 독립변수의 조작적 정의

\begin{tabular}{|c|c|c|c|}
\hline $\begin{array}{c}\text { 변수의 } \\
\text { 개념적 정의 }\end{array}$ & 변수의 조작적 정의 & 측정항목 & $\begin{array}{l}\text { 가설의 주요 } \\
\text { 이론적 근거 }\end{array}$ \\
\hline 소비자 혁신성 & 혁신적 서비스 사용 & $\begin{array}{l}\text { - 무선인터넷 서비스 이용 } \\
\text { - 혁신적 부가 서비스 이용 }\end{array}$ & $\begin{array}{l}\text { Cestre and Darmon(1998), } \\
\text { Rogers(1976). Moore(1991) }\end{array}$ \\
\hline 소비자 지식 & 부가서비스 사용경험 & $\begin{array}{l}\text { - 부가서비스의 종류 수 } \\
\text { - 부가서비스 이용요금 } \\
\text { - 무선인터넷 서비스 이용 요금 }\end{array}$ & $\begin{array}{l}\text { Moreau, Lehmann and } \\
\text { Markman(2001) }\end{array}$ \\
\hline 제품 사용정도 & 통화서비스 사용정도 & $\begin{array}{l}\text { - 월평균 통화시간 } \\
\text { - 월평균 통화요금 } \\
\text { - 요금제 수준 }\end{array}$ & $\begin{array}{l}\text { Morgan (1979), } \\
\text { Goldsmith and Flynn(1994), } \\
\text { Goldsmith and Litvin(1999) }\end{array}$ \\
\hline $\begin{array}{l}\text { 고객 } \\
\text { 참여 }\end{array}$ & 로열티 프로그램 참여 & - 멤버십 서비스 가입 & $\begin{array}{l}\text { Langeard et al.(1981). } \\
\text { Andreasen(1983) }\end{array}$ \\
\hline \multicolumn{2}{|c|}{ 인구통계변수 } & $\begin{array}{l}\text { - 나이 } \\
\text { - 성별 }\end{array}$ & Im et al. (2003) \\
\hline
\end{tabular}

간, 월평균 통화요금, 그리고 요금제 수준으로 측정하였다.

넷째, 로열티 프로그램 참여의 측정항목은 소 비자가 멤버십 카드를 발급받았는지의 여부를 변수로 사용하였다.

다섯째, 인구통계변수로는 성별과 나이를 사 용하였다.

본 논문에서 사용된 독립변수들의 개념적 및 조작적 정의와 측정항목, 그리고 주요 이론적 근거를 위〈표 3-1〉에 정리하였다.

\section{3 분석방법}

본 논문에서는 기간분석(duration analysis)을 통해 가설을 검증하였는데 기간분석은 사건 (event)의 발생에 대한 종단(longitudinal) 자 료를 분석하는데 자주 쓰이는 방법이다. 교체 구매에 소요되는 기간이라는 종속변수에 영향
을 미치는 변수의 효과를 규명하기 위해 기존 의 전통적인 회귀분석을 적용한다면 다음과 같 은 문제가 발생하게 된다. 즉 우측 절단(right censored)된 데이터가 많아지면 회귀모형은 불 완전한 데이터로 인해 편향된(biased) 결과를 도출할 수 있다. 사건의 발생 여부에 대한 불확 실한 자료인 절단 관측치(censored data)는 비 록 기간은 불확실하지만 절단되기 직전까지는 사건이 발생하지 않았다는 부분적인 정보를 지 니고 있다. 기간분석에서는 이러한 점을 최대로 이용하여 분석할 수 있는 장점이 있다. 본 연구 에서도 관측 기간 내에 교체구매를 하지 않았 기에 그 기간을 정확히 알 수 없는 소비자가 $40 \%$ 를 차지하고 있기 때문에 기간분석의 활용 이 필요하다. 또 회귀분석으로는 교체 구매의 확률이 시간에 따라 변화하는 성질을 제대로 반영할 수 없다(Kalbfleisch and Prentice 1980). 위험모형(hazard model)은 이러한 데이터와 변 
수를 분석하기 위한 목적으로 개발되었으며, 지 속기간과 같은 변수를 연구하는데 적합하다 (Helsen and Schmittlein 1993).

교체구매 기간은 $\mathrm{f}(\mathrm{t})$ 라는 확률밀도함수와 $\mathrm{F}(\mathrm{t})$ 라는 누적밀도함수를 가진 확률변수를 이용하 여 정의할 수 있다. 위험률(hazard rate)은 아 래의 식과 같이 교체 구매라는 사건(event)이, $(0, \mathrm{t})$ 라는 시간구간에서 일어나지 않았다고 가 정할 때, $t$ 라는 시점에서 일어날 조건부 확률 이다. 따라서 본 연구에서 위험률은 소비자가 $\mathrm{t}$ 시점에 교체 구매 할 가능성이 된다.

$$
h(t)=f(t) /(1-F(t))
$$

본 연구에서 여러 변수들의 영향을 동시에 알 아보는 다변량 분석법이 요구되며 이러한 목적 에 $\operatorname{Cox}(1972)$ 모형이 유용하다. Cox모형은 생 존시간에 대해 어떠한 분포형태도 가정하지 않 으므로 비모수적이지만, 모형에 근거하여 회귀 계수를 추정한다는 점이 모수적 방법과 유사하 여 비모수와 모수의 중간형태 모형이다. 이는 비례적 위헙함수의 가정에서 출발하므로 비례위 험함수 회귀모형(proportional hazard formulation) 이라고도 한다. $\operatorname{Cox}$ 모형에서 $\mathrm{i}$ 번째 관측치의 위 험 함수는 다음과 같이 정의된다.

$$
\left.h_{i}(t \mid X)=h_{0}(t) \exp \left(-\beta X_{i}\right)\right)
$$

여기에서 $h_{0}(t)$ 는 기저 위험함수(baseline hazard)로서 지속기간과 위험비율의 관계를 설명 해주는 부분이고. 나머지는 독립변수를 결합시 키기 위한 부분이다. 독립변수 $\mathrm{X}$ 값의 변화가 기저위험함수를 위 또는 아래로 이동시키게 되
는 것이다. 이러한 비례위험함수의 추정을 위해 서는 부분 우도(partial likelihood) 방식에 의거하 여 준모수적 추정(semi-parametric estimation) 방식을 주로 사용한다. 부분 우도 방식이란 이 탈의 위험에 처한 모든 고객 중 $\mathrm{i}$ 번째 고객이 실제 해당 시점에서 이탈할 확률을 계산하는 것이며 우도함수(likelihood function)는 다음과 같이 표현된다(Greene 2000).

$$
L\left(i \mid t, j_{1}, \ldots, j_{n(t)}\right)=e^{\beta x_{i t}} \bigwedge_{k=1}^{n(t)} e^{\beta x_{j k t}}
$$

$\operatorname{Cox}$ (1972)의 비례위험모형은 기저 위험함수 의 분포를 가정할 필요가 없으므로 편리하고, 시간에 따라 변하는 독립변수를 모형에 결합하 기가 용이하다는 강점을 가지고 있어 일반적으 로 많이 쓰인다. 본 연구에서도 SAS프로그램 의 PROC PHREG 명령어를 사용하여 준모수 적 추정을 통해 가설을 검증하였다.

\section{4 기술통계}

자료의 소비자 총 150 명 중 교체 구매를 한 사 람은 91 명 $(60.7 \%)$, 하지 않은 사람은 59 명이었 다. 각 변수의 기술 통계를 자료전체와 교체구 매 여부에 따라서 구분하여 살펴보면 다음의 〈표 3-2〉와 같다. 
〈표 3-2〉 각 변수의 기술 통계 분석`

\begin{tabular}{|c|c|c|c|c|}
\hline 변수 & 설명 & $\begin{array}{c}\text { 전체 평균 } \\
\text { 및 표준편차 }\end{array}$ & $\begin{array}{c}\text { 교체구매 한 } \\
\text { 사람의 평균값 }\end{array}$ & $\begin{array}{l}\text { 교체구매하지 않은 } \\
\text { 사람의 평균값 }\end{array}$ \\
\hline 교체구매 기간 & $\begin{array}{c}\text { 단말기를 } \\
\text { 교체한 기간(일) }\end{array}$ & $\begin{array}{r}155.74 \\
(80.11) \\
\end{array}$ & $\begin{array}{r}160.77 \\
(75.66) \\
\end{array}$ & $\begin{array}{r}147.98 \\
(86.62) \\
\end{array}$ \\
\hline 요금제 수준 & $\begin{array}{c}\text { 월 단위 } \\
\text { 기본요금(원) }\end{array}$ & $\begin{array}{r}13,465 \\
(8,789)\end{array}$ & $\begin{array}{r}15,390 \\
(8,282)\end{array}$ & $\begin{array}{r}10,497 \\
(8,788)\end{array}$ \\
\hline $\begin{array}{c}\text { 무선인터넷 } \\
\text { 이용 }\end{array}$ & $\begin{array}{c}1: \text { 사용, } \\
0: \text { 사용 안함 }\end{array}$ & $\begin{array}{r}0.22 \\
(0.42)\end{array}$ & $\begin{array}{r}0.33 \\
(0.47) \\
\end{array}$ & $\begin{array}{r}0.05 \\
(0.22)\end{array}$ \\
\hline $\begin{array}{c}\text { 부가서비스 } \\
\text { 종류 수 }\end{array}$ & $\begin{array}{c}\text { 가입된 } \\
\text { 서비스 수 }\end{array}$ & $\begin{array}{r}0.96 \\
(0.73)\end{array}$ & $\begin{array}{r}1.23 \\
(0.67)\end{array}$ & $\begin{array}{r}0.54 \\
(0.62)\end{array}$ \\
\hline $\begin{array}{c}\text { 혁신적 } \\
\text { 부가서비스 }\end{array}$ & 5점 척도 & $\begin{array}{r}1.97 \\
(1.69) \\
\end{array}$ & $\begin{array}{r}2.70 \\
(1.61) \\
\end{array}$ & $\begin{array}{r}0.85 \\
(1.11) \\
\end{array}$ \\
\hline 나이 & 평균 나이(세) & $\begin{array}{r}34.36 \\
(12.63) \\
\end{array}$ & $\begin{array}{r}29.71 \\
(9.97) \\
\end{array}$ & $\begin{array}{r}41.64 \\
(13.00) \\
\end{array}$ \\
\hline 성별 & $\begin{array}{c}\text { 1:남자. } \\
0 \text { :여자(명) }\end{array}$ & $\begin{array}{r}0.60 \\
(0.49)\end{array}$ & $\begin{array}{r}0.58 \\
(0.50)\end{array}$ & $\begin{array}{r}0.62 \\
(0.49)\end{array}$ \\
\hline 멤버십 가입 & $\begin{array}{c}1: \text { 가입, } \\
0: \text { 가입 안함 }\end{array}$ & $\begin{array}{r}0.46 \\
(0.50)\end{array}$ & $\begin{array}{r}0.62 \\
(0.49)\end{array}$ & $\begin{array}{r}0.21 \\
(0.41)\end{array}$ \\
\hline 월평균 요금 & $\begin{array}{c}\text { 최근 } 3 \text { 개월 } \\
\text { 평균 요금(원) }\end{array}$ & $\begin{array}{r}28,442 \\
(21,076)\end{array}$ & $\begin{array}{r}33,186 \\
(22,184)\end{array}$ & $\begin{array}{r}21,123 \\
(16,961)\end{array}$ \\
\hline $\begin{array}{c}\text { 월평균 } \\
\text { 통화 시간 }\end{array}$ & $\begin{array}{c}\text { 최근 } 3 \text { 개월 } \\
\text { 평균 통화량(분) }\end{array}$ & $\begin{array}{r}72.94 \\
(83.85)\end{array}$ & $\begin{array}{r}88.51 \\
(98.29) \\
\end{array}$ & $\begin{array}{r}48.51 \\
(44.81)\end{array}$ \\
\hline $\begin{array}{c}\text { 부가서비스 } \\
\text { 요금 }\end{array}$ & $\begin{array}{c}\text { 최근 3개월 } \\
\text { 평균 요금(원) }\end{array}$ & $\begin{array}{r}3,099 \\
(3,648) \\
\end{array}$ & $\begin{array}{r}3,835 \\
(4,017) \\
\end{array}$ & $\begin{array}{r}1,962 \\
(2.643) \\
\end{array}$ \\
\hline $\begin{array}{c}\text { 무선인터넷 } \\
\text { 요금 }\end{array}$ & $\begin{array}{c}\text { 최근 } 3 \text { 개월 } \\
\text { 평균 요금(원) }\end{array}$ & $\begin{array}{r}6,027 \\
(9,791)\end{array}$ & $\begin{array}{r}9,097 \\
(11,263)\end{array}$ & $\begin{array}{r}1,292 \\
(3,437)\end{array}$ \\
\hline
\end{tabular}

* 1,0 의 값을 갖는 명목척도의 평균값은 1 의 값을 갖는 응답자의 비율로 해석한다.

\section{5 가설 검증 및 펑가}

\subsection{1 모형과 가설의 검증}

가설 검증을 위하여 먼저 모형의 전반적 유의 성을 평가하였으며, 포함된 변수들의 계수 값을 측정하고 유의성을 테스트하였다. 비례 위험함
수 분석에서 모형의 유의성은 모든 변수의 계 수가 0 이라는 귀무가설을 검정한다. 우도비 검 정(likelihood ratio test) 결과 모형이 전체적으 로 유의한 것으로 나타났다(p<.0001).〈표 3-3〉 은 개별 변수만으로 이루어진 모형, 모든 변수 가 함께 고려된 완전 모형(full model), 그리고 일부 변수들만을 포함시킨 매우 다양한 종류의 
〈표 3-3〉 모형 추정 결과

\begin{tabular}{|c|c|c|c|c|c|c|c|}
\hline \multirow{2}{*}{ 변수의 종류 } & \multirow[b]{2}{*}{ 변수 } & \multicolumn{2}{|c|}{$\begin{array}{l}\text { 개별 } \\
\text { 모형 }\end{array}$} & \multicolumn{2}{|c|}{$\begin{array}{l}\text { 완전 } \\
\text { 모형 }\end{array}$} & \multicolumn{2}{|c|}{$\begin{array}{l}\text { 내포 } \\
\text { 모형 }\end{array}$} \\
\hline & & 계수 값 & 위험 비율 & 계수 값 & 위헙 비율 & 계수 값 & 위헙 비율 \\
\hline \multirow{2}{*}{$\begin{array}{c}\text { 혁신적 } \\
\text { 서비스 사용 }\end{array}$} & $\begin{array}{c}\text { 무선인터넷 } \\
\text { 이용여부 }\end{array}$ & $1.40536^{* * *}$ & 4.077 & 0.13895 & 1.149 & - & - \\
\hline & $\begin{array}{l}\text { 혁신적 부가 } \\
\text { 서비스 이용 }\end{array}$ & $0.59550^{* * *}$ & 1.814 & $0.26240^{*}$ & 1.300 & $0.27189^{* * *}$ & 1.312 \\
\hline \multirow{3}{*}{$\begin{array}{c}\text { 서비스 } \\
\text { 사용경험 }\end{array}$} & $\begin{array}{c}\text { 부가서비스 } \\
\text { 종류 수 }\end{array}$ & $1.02988^{* * *}$ & 2.801 & $0.64983^{* *}$ & 1.915 & $0.57724^{* * *}$ & 1.781 \\
\hline & $\begin{array}{c}\text { 부가서비스 } \\
\text { 이용요금 }\end{array}$ & $0.0001154^{* * *}$ & 1.000 & 0.0000298 & 1.000 & - & - \\
\hline & $\begin{array}{c}\text { 무선인터넷 } \\
\text { 이용요금 }\end{array}$ & $0,0000557^{* * *}$ & 1.000 & 0.0000133 & 1.000 & $0.0000225^{* *}$ & 1.000 \\
\hline \multirow{3}{*}{$\begin{array}{c}\text { 통화 } \\
\text { 서비스 } \\
\text { 사용정도 }\end{array}$} & $\begin{array}{c}\text { 월평균 } \\
\text { 통화시간 }\end{array}$ & $0.0000597^{* * *}$ & 1.000 & 0.0000008 & 1.000 & - & - \\
\hline & $\begin{array}{c}\text { 월평균 } \\
\text { 통화요금 }\end{array}$ & $0.0000126^{* * *}$ & 1.000 & 0.0000004 & 1.000 & - & - \\
\hline & $\begin{array}{l}\text { 요금제 } \\
\text { 수준 }\end{array}$ & $0.0000544^{* * *}$ & 1.000 & $-0.0000377^{*}$ & 1.000 & - & - \\
\hline $\begin{array}{c}\text { 로열티 } \\
\text { 프로그램 } \\
\text { 참여 }\end{array}$ & $\begin{array}{c}\text { 멤버십 } \\
\text { 가입여부 }\end{array}$ & $1.08082^{* * *}$ & 2.947 & $0.55526^{* *}$ & 1.742 & $0.46175^{*}$ & 1.587 \\
\hline \multirow{2}{*}{$\begin{array}{c}\text { 인구통계 } \\
\text { 변수 }\end{array}$} & 나이 & $-0.07325^{* * *}$ & 0.929 & $-0.05548^{* * *}$ & 0.946 & $-0.04432^{* * *}$ & 0.957 \\
\hline & 성별 & 0.11069 & 1.117 & $0.42492^{*}$ & 1.529 & - & - \\
\hline
\end{tabular}

${ }^{*} \mathrm{p}<0.10 ;{ }^{* *} \mathrm{p}<0.05 ;{ }^{* * *} \mathrm{p}<0.01$

내포 모형(nested model)들 중에서 가장 적합 도가 높은 내포 모형 하나에 대한 추정결과와 각 독립변수의 유의성 여부를 보여주고 있다.

〈표 3-3〉의 완전모형의 추정 결과에 따르면 무선인터넷 서비스의 이용여부는 교체구매 기 간에 영향을 미치지 않았으나. 혁신적인 부가서 비스를 이용하는 소비자일수록 소비자의 혁신 성이 높기 때문에 교체구매 기간이 짧아질 것 이라는 가설의 경우 $90 \%$ 유의수준에서는 유의
한 것으로 나타났고, 5 개 변수만 고려한 내포 모형에서는 매우 유의하게 나타났다.

소비자의 부가서비스 사용경험과 관련된 변수 들 중에서는 부가서비스 종류 수가 유의한 것 으로 나타났다. 사용하는 부가서비스 종류의 수 가 하나 더 늘수록 교체구매를 할 가능성, 즉 위험률이 $91.5 \%$ 나 증가한다. 부가서비스의 이 용시간 변수는 유의하지 않았다. 무선인터넷 서 비스 이용시간이 길수록 교체구매 기간이 짧아 
질 것이라는 가설도 5 개 변수만 고려한 내포 모형에서는 유의하게 나타났다.

통화서비스 사용정도에 대한 가설은 어느 것 도 채택되지 않았다. 특히 요금제 수준에 대한 가설은 예상했던 부호와 반대의 결과를 보이고 있는데. 이는 개별모형을 검증했을 때 양의 상 관관계로 유의하게 나타났다는 사실과 비교해 보았을 때 다중공선성의 문제로 생각할 수 있 다. 개별적으로는 유의한 변수라도 연관성이 높 은 변수들을 함께 고려한다면 유의하지 않은 결과를 보일 수 있기 때문이다. 월평균 통화요 금이나 부가서비스 요금도 모두 유의하지 않았 다. 따라서 통화시간이 긴 헤비 유저와 교체구 매 기간의 관련성은 적은 것으로 판단된다.

로열티 프로그램에 참여한 소비자가 그렇지 않 은 소비자보다 교체구매 기간이 짧을 것이라는 가설은 채택되었다. 그러므로 실무자의 관점에서 멤버십 서비스와 같이 서비스 제공자와 고객 간 의 관계를 강화하는 마케팅 전략이 제품 교체구 매를 활성화하는데 효과적인 것으로 보인다.

나이가 적을수록 교체 구매 기간이 단축될 것 이라는 가설은 채택되었다. 위험비율 $94.6 \%$ 가 의 미하는 바는 나이가 한 살 더 많아지는 만큼 교 체구매 할 위험률(hazard rate)이 $54 \%$ 만큼 줄어 든다는 것이다. 성별은 $95 \%$ 유의 수준에서는 채 택되지 않지만 $90 \%$ 수준에서 유의하므로 교체구 매 기간과 관련성이 있는 것으로 보이며, 남자가 여자보다 휴대폰 교체시기가 빠른 경향을 보였다.

\section{5 .2 모형의 적합도 및 예측 타당성}

특정 사용자의 변수(covariate)의 값을 알면 추정된 위험함수 모형을 통하여 교체구매 시기
를 예측할 수 있다. 예측을 위하여 사용되는 효 과적이고 효율적인 모형을 찾기 위하여 〈표 3-4>에서는 완전 모형(full model) 과 유의하지 않은 변수를 제외한 내포 모형(nested model) 을 비교하였다. 만약 어느 변수군을 제외하였을 때 그 내포 모형이 완전 모형과 통계적으로 다 르지 않다면 예측의 목적으로 모형을 활용할 때 그 변수들을 포함시키지 않아도 무방하므로 자료수집에 있어 효율성을 높일 수 있기 때문 이다. 또 Redman(1996)은 고객의 이해를 위한 데이터는 풍부할수록 좋지만, 과다한 정보는 비 용을 증가시키고 더 중요한 정보로부터 주의를 분산시킨다고 하였다. 그러므로 완전모형과 부 분모형을 비교함으로써 교체구매 기간을 예측 하기 위한 목적으로 사용할 때 가장 경제적인 모형이 어떤 것인지를 알아보고자 하였다.

모형의 적합도는 - $2 \log \mathrm{L}$ 혹은 AIC(Akaike's information criterion)나 $\mathrm{SBC}$ (Schwarz's Bayesian criterion)에서 적은 수치를 얻을수록 더욱 높은 데, 내포 모형의 적합도가 완전 모형의 적합도 에 비해 크게 다르지 않음을 알 수 있다. 따라 서 상황에 따라 내포 모형에 포함된 변수들만 을 가지고 교체구매 기간을 비교적 정확하게 예측할 수 있다. 다만, 본 연구에서 사용된 표 본의 수가 적기 때문에 실제 소비자의 이질성 이 충분히 반영되지 못했을 가능성이 있으므로 실무 적용을 위해서는 철저한 검증이 필요할 것이다.

도출된 모형의 예측 타당성을 살펴보기 위해 응답자들의 교체구매 기간을 예측하여 실제 값 과 비교해 보았다. 관측치가 150 개로 적기 때문 에 기간예측을 위해서 4 개의 동일한 크기의 하 위 표본(sub samples)으로 나누는 방법을 선택 
〈표 3-4〉 완전 모형과 내포 모형의 적합도 비교

\begin{tabular}{|c|c|c||c|c|}
\hline & \multicolumn{2}{|c||}{ 완전 모형 } & \multicolumn{2}{c|}{ 내포 모형 } \\
\hline & $\begin{array}{c}\text { Without } \\
\text { Covariates }\end{array}$ & $\begin{array}{c}\text { With } \\
\text { Covariates }\end{array}$ & $\begin{array}{c}\text { Without } \\
\text { Covariates }\end{array}$ & $\begin{array}{c}\text { With } \\
\text { Covariates }\end{array}$ \\
\hline$-2 \log \mathrm{L}$ & 713.699 & 607.864 & 720.154 & 618.264 \\
\hline $\mathrm{AIC}$ & 713.699 & 629.864 & 720.154 & 628.264 \\
\hline $\mathrm{SBC}$ & 713.699 & 657.362 & 720.154 & 640.763 \\
\hline
\end{tabular}

〈표 3-5〉 완전모형의 예측기간과 실제기간

\begin{tabular}{|c|c|c|}
\hline & 실제 값 & 예측된 값 \\
\hline 교체 구매 한 사람 & 91 명 & 82 명 \\
\hline 평균 교체 구매 기간 & 197.40 & 206.54 \\
\hline 기간 표준편차 & 90.40 & 81.26 \\
\hline
\end{tabular}

하였다. 즉, 모형을 3 개의 하위 표본에 적용하 여 얻은 위험 모형의 추정값을 나머지 표본의 교체 구매 기간을 예측하는데 사용하고 이러한 과정을 모든 표본들에 동일하게 반복하였다. 완 전모형의 $\mathrm{MAE}$ 는 45 일, $\mathrm{RMSE}$ 는 54 일로 나타 났고 교체구매를 한 사람을 대상으로 하여 실 제 값과 예측된 평균 교체구매 기간을 예측한 결과 차이가 10 일 이내 수준으로서 예측 타당 성을 증명해주고 있다(〈표 3-5〉 참조).

\section{N. 결론 및 시사점}

\section{1 연구 결과의 요약 및 시사점}

본 연구가 가지는 의의는 다음과 같다. 첫째, 휴대폰의 교체수요가 급증하고 있는 가운데 교 체구매에 대한 소비자의 톡성 및 구매 행동의
이해는 반드시 필요하다. 소비자의 교체구매 중 에서도 기간에 관한 연구는 아직 활성화되지 않은 분야이나 경쟁이 치열해지는 내구재의 신 제뚬 확산 측면에서 매우 중요성이 크다고 본 다. 본 논문은 신제품 출시가 매우 활발하고 교 체구매 시장의 경쟁이 치열한 휴대폰이라는 내 구재의 교체구매 타이밍에 대한 기간분석을 시 도했다는 데 의의가 있다.

둘째, 이동통신 서비스 기업에서 실제로 수집 한 자료를 사용하여 교체구매 기간을 측정하였 고 여러 번수로부터 얻어진 모형을 사용하여 타이밍을 예측할 수 있었다. 내포 모형에 포함 된 5 가지 변수들만 가지고도 교체구매 기간을 비교적 완전하게 예측할 수 있었으므로 이동통 신 회사들이 보유하고 있는 한정된 자료를 통 해서도 교체구매 기간에 대한 효율적인 예측이 가능하다는 것을 보였다.

2004년 국내 정보통신서비스 시장은 디지털 콘텐츠와 이동전화 번호이동성 및 데이터 서비 
스 수요에 힘입어 전년대비 $6.3 \%$ 의 성장률을 기록하고 2005년 이후에는 연평균 $4.8 \%$ 씩 성 장, 2008년에는 55 조 4 천억 원의 시장규모를 형 성할 것으로 예측되는데(IT산업전망 컨퍼런스 2004) 성장의 하향은 경기 침체와 더불어 정보 통신 시장이 이미 성숙기에 접어들었기 때문에 나타난다. 이러한 상황에서 기존 고객을 유지하 는 것이 서비스 제공업자에게 더욱 중요한 사 안으로 떠오르고 있다. 따라서 기업 내에 보유 하고 있는 고객 데이터, 즉 서비스 이용과 관련 된 소비자 행동 변수와 인구통계 변수를 활용 한다면. 고객의 단말기 교체를 적절히 관리하여 고객을 자사의 서비스에 고착시키고(lock-in) 이른바 업셀링(up-selling)을 할 수 있는 이점 을 얻을 수 있을 것이다.

본 연구는 휴대폰 사용자가 신제품으로 교체 구매를 하는데 소요되는 기간에 영향을 주는 변수들의 효과를 규명하는 것을 목적으로 하였 는데 본 연구에서 도출된 결과와 실무적 시사 점을 요약하면 다음과 같다.

첫째, 무선인터넷 이용 여부는 휴대폰 교체구 매 기간에 영향을 미치지 않는 것으로 나타났 으나. 혁신적인 부가서비스를 사용하는 고객의 경우 교체구매 기간이 짧은 것으로 드러나 혁 신적 부가서비스에 대한 적극적인 마케팅이 교 체구매 촉진에 유용함을 알 수 있다.

둘째, 다양한 종류의 부가서비스를 사용할수 록 소비자의 서비스 사용지식이 많아 제품 교 체구매 의사결정 과정을 신속하게 하는 경향이 있음을 파악하였다. 휴대전화의 기본서비스라 할 수 있는 통화서비스나 무선인터넷 서비스 이용정도 등은 교체구매 기간과 관련성이 적은 것으로 나타났다.
셋째, 로열티 프로그램에 참여한 소비자일수 록 교체구매 기간이 감소할 것이라는 일반적인 기대를 실증적으로 확인하였다. 멤버십 서비스 와 같이 서비스 제공자와 고객과의 관계를 강 화하는 마케팅 전략이 제품 교체구매를 활성화 하는데 효과적일 것으로 보인다.

마지막으로 나이가 적은 소비자이거나 남성일 수록 휴대폰의 신제품에 보다 민감하다는 것을 알 수 있었으며. 나이가 성별보다 교체구매 기 간에 영향을 미치는 효과가 컸다.

\section{2 연구의 한계 및 향후 연구 과제}

본 연구의 한계점과 향후 연구과제는 다음과 같다.

첫째, 종속변수인 교체구매 기간은 최근 휴대 폰을 교체 구매한 날짜와 그 이전에 구매하였 던 날짜 사이의 기간이다. 제공받은 자료의 경 우 1 년 동안 기기를 두 번 구매한 고객만이 교 체 구매한 고객이 되며, 한 번만 구매한 고객은 분석 기간의 마지막 일자에서 절단(censor)된 것으로 간주되었다. 따라서 짧은 기간에 존재한 관측치 만을 분석하였고 1 년 이상 장기간에 걸 쳐 교체 구매한 고객은 분석할 수 없었다는 한 계가 존재한다. 더욱 높은 예측 타당성을 가지 는 모형을 얻기 위해서는 보다 장기간에 걸친 자료가 필요할 것이다.

둘째, 기업 내 보유하고 있는 고객 자료만으 로 분석하였기 때문에 그 외의 중요한 변수들 이 고려되지 못한 한계가 존재한다. 예를 들어 제품의 어떠한 속성이 소비자의 교체구매 행동 과 관련되는지는 알 수 없는 것이다. 이는 $\mathrm{Kim}$ and Srinivasan(2003)의 교체구매 연구와 같이 
컨조인트 모형을 위험 모형과 복합적으로 사용 함으로써, 제품 속성에 대한 소비자의 선호를 고려한다면 어느 정도 해결될 수 있을 것이다.

셋째, 경쟁변수를 고려하지 않고 한 기업의 고객 자료를 분석하였기 때문에 당해 기업 제 품이나 서비스에 기인한 특수적인 효과가 존재 한다면 타사에 일반화하여 적용하는데 한계가 있을 수 있다. 마케팅 변수가 교체구매 결정의 타이밍을 가속화 할 수 있음에도 불구하고 그 러한 변수를 고려할 수 없었던 것도 한계이다. 광고나 프로모션, 유통 등 마케팅 변수까지 모 형에 포함시킨다면 소비자의 교체구매에 대하 여 더욱 많은 관리적인 시사점을 제공받을 수 있을 것이다.

마지막으로 통화량이나 통화요금, 부가서비스 이용요금 등과 같은 변수는 매월 수치가 달라 지고 시간에 따라 추세가 변화할 수 있기 때문 에, 단순하게 평군값을 쓰는 것보다 시간에 따 라 변하는 독립변수들로써 모형에 추가한다면 더욱 정확한 추정과 예측 타당성을 얻을 수 있 으리라 여겨진다.

〈논문 접수일: 2005. 02. 04〉 〈게재 확정일: 2005. 05. 06〉

\section{참고문헌}

박정은, 채서일, 이성호(1998), “서비스 제공자 와 소비자 간의 관계의 질이 만족과 재구매 의도 관계에 미치는 조정역할에 관한 탐색적 연구," 마케팅연구. 제13권 제2호, 119-139. IT산업전망 컨퍼런스 2005(2004), 정보통신서비
스 시장현황 및 전망.

유필화, 이승희(1994), “신제품 수용시 소비자의 혁신저항에 관한 연구," 경영학연구, 제 3 권, 217-250.

최낙한, 황윤용(1998), "소비자의 심리적 애호도 와 제품 평가에 관한 사전 지식의 구조적 역할에 관한 연구," 소비자학연구, 제 9 권 제4호, 35-61.

코리안클릭(2003), 인터넷 사용 실태 및 사용자 의 특성조사.

한국소비자보호원(2001), 이동전화서비스 요금 및 소비자이용실태 조사결과.

한국인터넷정보센터(2003), 2003년 모바일인터 넷 이용실태조사.

Alba, J.W. and J.W. Hutchinson(1987), "Dimensions of Consumer Expertise," Journal of Consumer Research, March, 411-454.

Andreasen, Alan R.(1983), "Maintaining Growth in Non-Profit Consumer Research," $A d$ vances in Consumer Research, 10(1), 53-70. Assael, Henry and Poltrack, David F.(1994), "Can demographic profiles of heavy users serve as surrogate for purchase behavior in selecting TV programs?," Journal of Advertising Research, 34(1), 11-17.

Baumgartner, Hans and Jan-Benedict E. M. Steenkamp (1996), "Exploratory Consumer Buying Behavior: Conceptualization and Measurement," International Journal of Research in Marketing. 13, 121-137.

Bayus, Barry L.(1988), "Accelerating the Durable Replacement Cycle with Marketing Mix Variables," The Journal of Product In- 
novation Management, 5, 216-26.

(1991), "The Consumer Durable

Replacement Buyer," Journal of $\mathrm{Mar}^{-}$ keting, 55(January), 42-51. (1992), "The Dynamic Pricing of Next Generation Consumer Durables," Marketing Science, 11(3), 251-265. and Raj Mehta(1995), “A Segmentation Model for the Targeted Marketing of Consumer Durables," Journal of Marketing Research, 32(November), 463-469.

Berry, L.L. and Parasuraman, A.(1993), "Building a New Academic Field - The Case of Services Marketing," Journal of Retailing, Spring, 13-60.

Bettman, J. R. and C. W. Park(1980), "Effects of Prior Knowledge and Experience and Phase of the Choice Process on Consumer Decision Processes," Journal of Consumer Research. December, 234-248.

Brucks, Merrie(1985), "The Effect of Product Class Knowledge on Information Search Behavior," Journal of Consumer Research, 12(1). 1-16.

Cestre, Ghislaine, and Rene Y. Darmon(1998). "Assessing Consumer Preferences in the Context of New Product Diffusion," International Journal of Research in Marketing, 15, 123-135.

Cosby Lawrence A.(1989), Building and Maintaining Quality in Service Relationship, Stephen W. Brown and Evert Gummesson, eds. Lexington MA: Lexington Books. Kenneth R. Evans, and Deborah Cowles(1990), "Relationship Quality in Services Selling": An Interpersonal Influence Perspective, Journal of Marketing. 54(July), 68-81. and Nancy Stephens(1987), "Effects of Relationship Marketing on Satisfaction, Retention, and Prices in the Life Insurance Industry," Journal of Marketing Research, 24(November), 404-11. Cox, D.(1972), "Regression Models and Life Tables(with Discussion)," Journal of Royal Statistical Society Bulletin, 34, 187-220.

Cronin J. Joseph, Jr. and Steven A. Taylor(1992). "Measuring Service Quality: Reexamination and Extension," Joumal of Marketing, 56(3), 55-68.

DeBell, M. and R. Dardis(1979), "Extending Product Life: technology isn't the only issue." in Advances in Consumer Research. $381-5$.

Engel, J. F., R. D. Blackwell, and P.W. Miniard (1995), Consumer Behavior, 8th Edition. Dryden Press.

Eliashberg, Jehoshua, and Thomas S. Robertson (1988), "New Product Preannouncing Behavior: A Market Signaling Study," Journal of Marketing Research, 25(August), 282-92.

Goldsmith, Ronald E.(2001), "Using the Domain Specific Innovativeness Scale to identify innovative Internet consumers," Internet 
Research, 11(2), 149. and Francois d'Hauteville(1998),

"Heavy Wine Consumption: Empirical and Theoretical Perspectives," British Food Journal, 100(4), 184. and Stephen W. Litvin(1999), "Heavy Users of Travel Agents: A Segmentation Analysis of Vacation Travelers," Journal of Travel Research, 38(November), 127-133.

and Flynn, Leisa Reinecke (1994), "An Empirical Study of Heavy Users of Travel Agencies," Journal of Travel Research, 33, 38-43. and Hofacker, Charles F.(1991), "Measuring Consumer Innovativeness," Journal of the Academy of Marketing Science, 19(3), 209-222.

Goodwin, Cathy and Russell Radford(1993), "Models of Service Delivery: An Integrative Perspective," Advances in Services Marketing and Management, 2, 231-252.

Greene, William H.(2000), Econometric Analysis, Fourth Edition, Prentice Hall, Inc.

Heide, Jan B. and Allen M Weiss(1995), "Vendor Consideration and Switching Behavior for Buyers in High-Technology Markets," Journal of Marketing, 59(July), 30-43.

Helsen, Kristiaan and David C. Schmittlein (1993). "Analyzing Duration Times in Marketing: Evidence for the Effectiveness of Hazard Rate Models," Marketing Science. 12(Fall), 395-414.
Hoffer, George and Robert Reilly(1984), "Automobile Styling as a Shift Variable: an Investigation by Firm and by Industry." Applied Economics, 16, 291-297.

Hoyer, W.D., and Ridgway, N. N.(1984), "Variety Seeking as an Explanation for Exploratory Purchase Behavior: A Theoretical Model," Advances in Consumer Research, 11, 114-119.

Im, Subin, Barry L. Bayus and Charlotte H. Mason(2003), "An Empirical Study of Innate Consumer Innovativeness, Personal Characteristics, and New-product Adoption Behavior," Journal of the Academy of Marketing Science, 31(1), 61 - 73.

Katona, George(1960), The Powerful Consumer, Mc Graw-Hill Book Company. and Eva Muller(1954), "A Study of Purchase Decisions," The Dynamics of Consumer Behavior, 1, 30-87.

Kalbfleisch, John D. and Robert L. Prentice (1980), The Statistical Analysis of Failure Time Data. NY: Wiley.

Kelley, Scott W., Donnelly Jr., James H. and Skinner, Steven J.(1990), "Customer Participation in Service Production and Delivery." Journal of Retailing, 66(3). 315-335.

Kim, Sang-Hoon and V. Srinivasan(2003). "A Multiattribute Model of the Timing of Buyers' Upgrading to Improved Versions of High Technology Products," GSB Research Paper \#1720(R), Stanford University. Langeard, E.. J. E. G. Bateson, C. H. Lovelock. 
and P. Eiglier(1981), "Services Marketing:

New Insights from Consumers and Managers," report, Marketing Science Institute, Cambridge, MA.

Leavitt, Clark and John Walton(1975). "Development of a Scale for Innovativeness," $A d^{-}$ vances in Consumer Research, 2, 545-554.

Mason, Kevin and Bequette, Joyce(1998). "Product Experience and Consumer Product Attribute Inference Accuracy," The Journal of Consumer Marketing, 15(4), 343 357.

Mehrabian, A, and Russell, J.(1974), An Approach to Environmental Psychology, Cambridge, MA: MIT Press.

Moore, Geoffrey A.(1991), Crassing the Chasm, A Harper Business Book.

Moreau, C. Page, Donald R. Lehmann and Arthur B. Markman(2001), "Entrenched Knowledge Structures and Consumer Response to New Products," Journal of Marketing Research, 38(February), 14-29.

Morgan, Fred W., Jr.(1979), “Are Early Triers Heavy Users?" The Journal of Business, 52(3), 429-434.

Muller, Eva(1958), "The Desire for Innovations in Household Goods," in Consumer Behavior, Research on Consumer Reactions. 13-37.

Park, C. W.. David L. Mothersbaugh, and Lawrence Feich(1994), "Consumer Knowledge Assessment." Joumal of Consumer Research. 21(June), 71-82.

Quelch, John A.. Scott A. Neslin, and Lois B.
Olson(1987), "Opportunities and Risks of Durable Goods Promotion." Sloan Management Review, 27(winter), 27-38.

Raju, P. S.(1980), "Optimum Stimulation Level: Its Relation to Personality, Demographics, and Exploratory Behavior," Joumal of Consumer Research, 7(December), 272-282.

Rao, A.R. and K.B. Monroe(1988), "The Moderating Effect of Prior Knowledge on Cur Utilization in Product Evaluations," Journal of Consumer Research, September, 253-264. Raymond, Jennie E, Beard, T Randolph, Gropper. Daniel M.(1993), "Modelling the Consumer's Decision to Replace Durable Goods: A Hazard Function Approach," Applied Economics, 25(10), 1287-1292.

Redman, Thomas C.(1996), Data Quality for the Information Age, Artech House, MA. Rethans, A.J.. J.L. Swasy, and L.J. Marks (1986), "Effects of Television Commercial Tepitition, Receiver Knowledge, and Commercial Length: A Test of the Two-Factor Model," Journal of Marketing Research, February, 50-61.

Robertson, T. and Kennedy, J.(1968), "Prediction of Consumer Innovators: Application of Multiple Discriminant Analysis." Joumal of Marketing Research, 5, 64-49.

Rogers, Everett M (1976), "New Product Adoption and Diffusion," Journal of Consumer Research, 2(4), 290-301.

Solomon, Michael R.. Carol Surprenant. John A. Czepiel, and Evelyn G. Gutman(1985), 
"A Role Theory Perspective on Dynamic Interactions: The Service Encounter," Journal of Marketing, 41(1), 99-111.

Swan, John E., Trawick, I. Fredrick and Silva, David W.(1985), "How Industrial Salespeople Gain Customer Trust," Industrial Marketing Management, 14(3), 203-211.

Thorelli, H. B., and Eagledow, J. H.(1980), "Information Seekers and Information System, A Policy Perspective," Journal of Marketing. 44, 9-27.
Twedt, D.W.(1964). "How Important to Marketing Strategy is the 'Heavy User'?" Journal of Marketing, 28(January), 71-72. Zeithaml, Valarie A., Parasuraman A., and Leonard L. Berry(1985), "Problems and Strategies in Service Marketing," Journal of Marketing, 49(Spring), 33-46.

Zuckerman, M(1979), Sensation Seeking: Beyond the Optimal level of Arousal, Hillsdale NJ: Lawrense Erlbaum. 


\title{
Telecommunication Service Usage as Predictor of the Timing of Handset Buyers' Replacement Purchases
}

\author{
Hyun Jung Park ${ }^{*}$ \\ Sang-Hoon Kim**
}

\begin{abstract}
With the explosive growth of mobile products industry, tons of newer versions of products are putting on the market. From the marketer's perspective, understanding consumers' replacement purchases, especially the replacement timing, is essential to product planning and selling. This study presents an approach to finding out factors influencing the timing of buyers' replacement purchases of cell phones, using duration analysis; a hazard function specification is applied to describe consumers' replacement timing decision. Based on the data collected from a mobile telecommunication company, five categories of factors have been inspected. These are consumer's innovative service usage, data service usage, voice service usage, participation in loyalty programs, and the demographic characteristics. The results of the study are as follows. Firstly, the positive coefficient of 'the number of related services used' suggests that the consumers who have more usage knowledge tend to replace faster. Secondly, customers participating in the membership service are positively associated with early replacement purchases. Lastly, younger customers(vs. older) and male(vs. female) customers turned out to replace cell phones earlier.
\end{abstract}

Keywords: replacement purchases, telecommunication, timing

* Doctoral student, College of Business Administration. Seoul National University

** Assistant professor of marketing. College of Business Administration. Seoul National University 